\title{
ПРОБЛЕМА ОПРЕДЕЛЕНИЯ ИНОСТРАННОГО ГРАЖДАНИНА ИЛИ ЛИЦА БЕЗ ГРАЖДАНСТВА КАК НОСИТЕЛЯ РУССКОГО ЯЗЫКА
}

\section{THE PROBLEM OF DEFINING A FOREIGN CITIZEN OR A STATELESS PERSON AS A NATIVE SPEAKER OF THE RUSSIAN LANGUAGE}

T. Rychkova

A. Burtseva

Summary. The authors of the article consider the problems of defining a foreign citizen or a stateless person as a native speaker of the Russian language. They conduct a comparative analysis of the old and new criteria presented to candidates at the interview. The authors conclude that due to the ambiguity of the concept of "native speaker", the commission faces a large number of problems, identify the causes of these problems and provide recommendations for their elimination.

Keywords: language proficiency assessment, commission for recognition of foreign citizens as native speakers of Russian, interview with foreigners, native speaker of Russian.
B статье рассматривается проблема определения иностранного гражданина или лица без гражданства как носителя русского языка. Члены комиссии УМВД Мурманской области по признанию иностранных граждан носителями русского проводят сравнительный анализ старых и новых критериев, предъявляемых кандидатам на собеседовании и приходят к выводу, что изза неоднозначности понятия «носитель языка» комиссия сталкивается с большим количеством проблем. В статье делаются попытки выявить причины этих проблем и даются рекомендации по их устранению.

В настоящий момент иностранцы имеют два варианта получения российского гражданства: в общем и упрощенном порядке. В первом случае претенденты на гражданство РФ должны получить сначала разрешение на временное проживание в России, потом вид на жительство и находиться в России по виду на жительство не менее 5 лет. Во втором варианте иностранные граждане, имеющие давние связи с Россией и владеющие свободно русским языком, могут получить статус носителя русского языка, и тогда продолжительность процесса получения гражданства значительно сокращается: можно сразу после получения вида на жительство

\author{
Рычкова Татьяна Александровна \\ К.филол.н., дочент, Мурманский арктический \\ государственный университет \\ rychkovata@yandex.ru \\ Бурцева Александра Вячеславовна \\ К.п.н., дочент, Санкт-Петербургский \\ политехнический университет Петра Великого \\ alexandraburtseva@yandex.ru
}

Аннотация. В статье рассматривается проблема определения иностранного гражданина или лица без гражданства как носителя русского языка. Члены комиссии УМВД Мурманской области по признанию иностранных граждан носителями русского проводят сравнительный анализ старых и новых критериев, предъявляемых кандидатам на собеседовании. Авторы приходят к выводу, что из-за неоднозначности понятия «носитель языка» комиссия сталкивается с большим количеством проблем. В статье делаются попытки выявить причины этих проблем и даются рекомендации по их устранению.

Ключевые слова: критерии оценки уровня владения русским языком, комиссия по признанию иностранных граждан носителями русского языка, собеседование с иностранцами, носитель русского языка.

обратиться за гражданством, уменьшаются сроки рассмотрения документов.

Определением кандидата как носителя русского языка занимается комиссия УМВД, в состав которой входят собственно специалисты УМВД и преподаватели вузов, имеющие квалификацию в области русского языка как иностранного. На основании личного опыта авторов статьи, являющихся членами комиссии по признанию носителями русского языка УМВД Мурманской области, можно утверждать, что из-за неоднозначности понятия «носитель языка», комиссия сталкивается с большим количеством проблем. На законодательном уровне не существует определения термина «носитель русского языка», в соответствующих документах только перечислены требования к кандидатам на получение этого статуса. Следует отметить, что некоторые из этих требований достаточно неопределенны и со временем претерпели изменения.

До недавнего времени требования к кандидатам на носителя русского языка определялись приказом МВД России от 28.09.2017 N738 «Правила проведения комиссией по признанию иностранного гражданина или 
лица без гражданства носителем русского языка собеседования с иностранным гражданином или лицом без гражданства».

16 апреля 2020 года вступил в силу новый приказ № 227 «Об организации работы комиссий по признанию иностранного гражданина или лица без гражданства носителем русского языка». В этом приказе предлагаются новые критерии определения уровня владения языка.

Согласно старому варианту приказа, в ходе собеседования иностранный гражданин должен был продемонстрировать несколько умений. Во-первых, иностранец должен был понимать и уметь интерпретировать неадаптированные тексты на любую тематику, включая абстрактно-философские, профессиональной ориентации, публицистические и художественные, а также тексты, обладающие подтекстовыми и концептуальными смыслами. Надо отметить, что формулировка данного требования очень неконкретна, и неясно, что следует понимать, к примеру, под «абстрактно-философскими текстами» и каков должен быть их уровень сложности. Для понимания терминологии философских текстов, их концептуальных и подтекстовых смыслов недостаточно владения русским языком, так как не каждый гражданин РФ сможет в рамках 30-минутного экзамена понять философский или, например, специализированный текст профессиональной ориентации и правильно выстроить рассуждение на эту тему. Таким образом, согласно этому критерию, иностранный гражданин должен не только свободно владеть русским языком, но и иметь высокий уровень образования. Однако, как свидетельствует практический опыт авторов статьи, большинство иностранцев, проходящих собеседование, имеют общее или средне-специальное образование и не обладают глубокими научными знаниями.

Во-вторых, кандидаты на собеседовании должны были максимально полно понимать содержание, в частности, радио- и телепередач, кинофильмов, телеспектаклей, пьес, записей публичных выступлений, свободно воспринимая социально-культурные и эмоциональные особенности речи говорящих, интерпретируя фразеологизмы, известные высказывания и скрытые смыслы. Таким образом, иностранные граждане должны были хорошо понимать культурные коды русской культуры. Как свидетельствует опыт авторов этой статьи, свободно интерпретировать, например, фразеологизмы могли только представители славянской культуры (как правило, граждане Украины), так как русские и украинские пословицы и поговорки похожи. Все остальные: граждане Азербайджана, Узбекистана, Таджикистана, Армении,в большинстве случаев понимали 2-3 фразеологизма. Возможно, это связано с тем, что в повседневной жизни иностранец редко сталкивается с использованием фра- зеологических единиц, и чтобы их выучить, он должен не только много разговаривать, и читать: как классическую литературу, так и произведения устного народного творчества. А учитывая общий невысокий уровень образования среднестатистического кандидата на собеседовании, задача интерпретации устойчивых выражения и разгадывания культурных кодов оказывалась для представителя неславянской культуры практически невыполнимой. В результате собеседование проходили, как правило, только украинцы, а представители других наций, даже свободно говорящие на русском, в большинстве случаев получали отказ.

В-третьих, иностранные граждане должны были уметь достигать поставленных целей коммуникации в ситуациях подготовленного и неподготовленного монологического и диалогического общения, в том числе публичного, демонстрируя различные тактики речевого поведения. Требование умения выстраивать монолог и диалог является обоснованным, однако фраза о демонстрации тактик речевого поведения выглядит неопределенной. Речевая тактика - это приём достижения коммуникативной цели в процессе речевого взаимодействия. Речевая тактика должна обеспечивать осуществление избранной коммуникативной стратегии и развёртывание избранного речевого жанра. К речевым тактикам относятся, например, речевое выражение одобрения, комплимент, демонстрация скромности, удивления, уступки и т.д. На взгляд авторов этой статьи, владение тактиками речевого поведения демонстрируют не столько владение языком, сколько коммуникативные навыки.

И наконец, иностранные граждане в процессе собеседования должны были уметь демонстрировать полное знание языковой системы и свободное владение средствами выразительности языка во всем многообразии лексико-грамматических, стилистических, синонимических и структурных отношений [1]. Это требование также выглядит завышенным с учетом того, что многие мигранты имеют невысокий уровень образования. Например, в работе комиссии УМВД по Мурманской области была ситуация, когда было необходимо определить уровень владения языком украинца-разнорабочего, проживавшего к моменту собеседования уже несколько лет в России. Его речь была бедной в плане лексики, монолог он выстраивал с трудом, использовал просторечия. При этом данный гражданин был родом из русскоязычного района Украины и не владел никаким другим языком, кроме русского. Но он определенно не соответствовал указанным критериям, и члены комиссии вынуждены были проголосовать против.

16 апреля 2020 года был опубликован новый приказ № 227 «Об организации работы комиссий по признанию 
иностранного гражданина или лица без гражданства носителем русского языка», в котором были даны новые критерии определения уровня владения языком, а также список вопросов для собеседования (ранее вопросы и демонстрационные материалы должны были подбирать члены комиссии самостоятельно).

В новом перечне требований к носителю русского языка только одно из требований осталось неизменным: иностранный гражданин по-прежнему должен «достигать поставленных целей коммуникации в ситуациях подготовленного и неподготовленного монологического и диалогического общения, в том числе публичного, демонстрируя различные тактики речевого поведения». И если необходимость умения строить монолог и вступать в диалог не вызывает сомнений, то формулировка «речевых тактик» по-прежнему остается достаточно неопределенной и способной вызвать проблемы в определении статуса носителя языка. На наш взгляд, умение использовать речевые тактики больше говорит об общей воспитанности и образованности человека, чем о его владении языком.

Согласно следующим требованиям, кандидат на собеседовании должен уметь инициировать диалог в бытовых ситуациях, поддерживать беседу, а также понимать информацию, представленную в отдельных диалогах и монологах социально-бытового и социально-культурного характера. В сравнении с предыдущим вариантом, когда иностранному гражданину предлагалось читать и интерпретировать философские, профессиональные тексты и радиоспектакли, здесь уровень требований очевидно снизился, а предметные знания испытуемого ограничились бытовым и социально-культурным общением. Это изменение объясняется тем, что в предыдущем варианте требования были сильно завышены, так как далеко не все носители русского языка способны свободно читать и интерпретировать философские и узкоспециализированные тексты - это определяется не столько уровнем владения языка, сколько областью интересов и образованием.

В соответствии с последним требованием, иностранный гражданин должен правильно оформлять высказывание грамматически и лексически [2]. Члены комиссии отмечают допущенные кандидатом орфоэпические, лексические, грамматические (морфологические и синтаксические) ошибки, и если их будет более 20, иностранца не признают носителем русского языка. По сравнению с предыдущим вариантом, когда от кандидата требовалось полное знание языковой системы и свободное владение средствами выразительности языка во всем многообразии лексико-грамматических, стилистических, синонимических и структурных отношений, здесь критерии оказались очень сильно упрощены и сведены толь- ко до фиксации лексико-грамматических нарушений. Отвечая на 3-5 вопросов, кандидат может допустить 19 ошибок, и его признают носителем языка.

Такое снижения уровня требований к иностранным гражданам, претендующим на статус носителя русского языка, может объясняться несколькими причинами.

Во-первых, требования в предыдущем варианте приказа от 27 сентября 2017 года, как уже неоднократно упоминалось, были сильно завышены. «Свободное владение средствами выразительности языка во всем многообразии лексико-грамматических, стилистических, синонимических и структурных отношений», умение «интерпретировать неадаптированные тексты на любую тематику, включая абстрактно-философские, профессиональной ориентации, публицистические и художественные, а также тексты, обладающие подтекстовыми и концептуальными смыслами» предполагает не только владение русским языком, но и высокий уровень образования. Среди членов комиссии неоднократно возникали споры по поводу того, можно ли считать человека, всю жизнь говорящего на русском языке (если он проживал, например, в русскоязычном районе Украины), но малообразованного, окончившего только среднюю школу и не умеющего свободно строить диалог и использовать богатства русской речи, считать носителем русского языка и все ли граждане Российской Федерации смогут в полной мере соответствовать этим критериям и свободно интерпретировать сложные научные тексты.

Во-вторых, снижение уровня требований объясняется сменой контингента. Если раньше абсолютное большинство кандидатов были гражданами Украины, то в настоящее время они освобождены от собеседования. 17 июня 2020 г. вступил в силу Федеральный закон от 18 марта 2020 г. № 58-Ф3 «О внесении изменений в статью 33.1 Федерального закона «О гражданстве Российской Федерации», освобождающий граждан Республики Белоруссии и Украины, свободно владеющих русским языком, при признании их носителями русского языка от прохождения собеседования. Соответственно, на собеседование теперь приходят большей частью представители неславянских народов - граждане Грузии, Азербайджана, Киргизстана, Узбекистана - а им в совершенстве овладеть русским сложнее, и допускают они намного больше ошибок. Если бы критерии оставались прежними, то носителями языка признавались бы единицы. По предположению авторов статьи, Управление по вопросам миграции УМВД РФ заинтересовано в том, чтобы часть будущих граждан Российской Федерации получала гражданство упрощенным путем, так как это уменьшает бюрократическую нагрузку учреждения. В соответствии с новыми, более демократичными пра- 
вилами, стать носителем русского языка может намного больше граждан.

Таким образом, сравнительный анализ старых и новых требований к иностранным гражданам и лицам без гражданства, претендующим на статус носителя русского языка показал, что уровень требований значительно снизился и стал более конкретным. Это объясняется тем, что уровень старых критериев был высоким даже для носителей близкородственных языков и подразумевал не просто знание русского языка, но и хорошее образование и начитанность, а для представителей неславянских народов (которые после марта 2020 года преобладают) являлся практически недостижимым. Новые критерии дают возможность получить статус носителя русского языка значительно большему количеству претендентов.

Но несмотря на снижение уровня требований к носителю русского языка, проблема неопределенности границ данного статуса остается. На данный момент необходимо разработать четкое определение «носителя русского языка» и разграничить на законодательном уровне понятия владения языком, поведенческой нормы и общего лингвокультурного образования.

\section{ЛИТЕРАТУРА}

1. Приказ МВД России от 28.09.2017 N738 «Правила проведения комиссией по признанию иностранного гражданина или лица без гражданства носителем русского языка собеседования с иностранным гражданином или лицом без гражданства».

2. Приказ УМВД России от 16.04 .2020 № 227 «0б организации работы комиссий по признанию иностранного гражданина или лица без гражданства носителем русского языка».

3. Статья 33.1 Федерального закона РФ от 31 мая 2002 года № 62-Ф3 «0 гражданстве Российской Федерации»).

( Р Рычкова Татьяна Александровна ( rychkovata@yandex.ru ), Бурцева Александра Вячеславовна ( alexandraburtseva@yandex.ru ). Журнал «Современная наука: актуальные проблемы теории и практики»

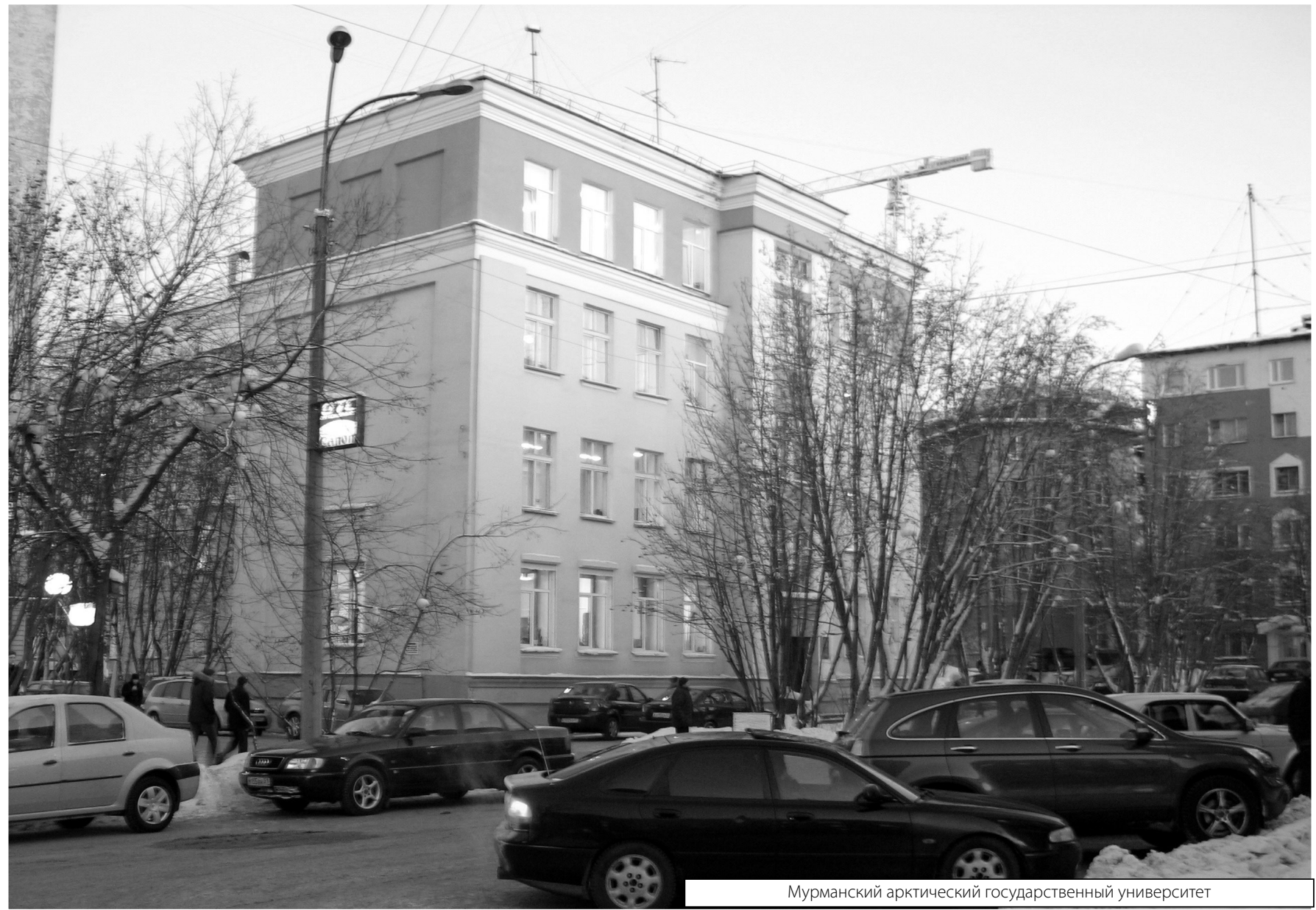

